\title{
Moral Identity and the Quaker tradition: Moral Dissonance Negotiation in the WorkPlace
}

\author{
Nicholas Burton ${ }^{1}$ (D) Mai Chi Vu'
}

Received: 20 December 2019 / Accepted: 6 May 2020 / Published online: 18 May 2020

(c) The Author(s) 2020

\begin{abstract}
Moral identity and moral dissonance in business ethics have explored tensions relating to moral self-identity and the pressures for identity compartmentalization in the workplace. Yet, the connection between these streams of scholarship, spirituality at work, and business ethics is under-theorized. In this paper, we examine the Quaker tradition to explore how Quakers' interpret moral identity and negotiate the moral dissonance associated with a divided self in work organizations. Specifically, our study illuminates that while Quakers' share a tradition-specific conception of "Quaker morality" grounded in Quaker theology and the Quaker testimonies to truth, integrity, peace, equality, and simplicity, they often foreground the pursuit of an undivided self through seeking work that enables an expression of Quaker moral identity, or by resigning from work organizations that do not. In most cases, however, Quakers' face moral dissonance at work and engage in either identity compartmentalization and draw upon the metaphor of a 'spiritual journey' as a form of self-justification, or reframe, compartmentalize and engage in work tasks that are both subjectively moral and meaningful. We present a model that elaborates these negotiation processes and invite further research that examines how the spiritual traditions influence moral identity construction at work.
\end{abstract}

Keywords Moral identity $\cdot$ Moral dissonance $\cdot$ Compartmentalization $\cdot$ Spirituality $\cdot$ Quaker

\section{Introduction}

The theoretical puzzle of how individuals negotiate moral identity and moral dissonance in business contexts has been investigated widely. For example, existing scholarship has stressed how moral identity is moderated by self-justification and affirmation (Leavitt et al. 2016; Lowell 2012; McFerranet al. 2010; Shao et al. 2008; Weaver 2006), and how individuals reframe behavior and action to fit with embedded moral ethics through a process of motivated reasoning (Kish-Gephart et al. 2014; Noval and Hernandez 2019; Zheng et al. 2019). However, the existing business ethics literature has largely disregarded how spiritual traditions connect to moral identity and moral dissonance at work, although with some notable exceptions (McGhee and Grant 2017; Rozuel 2011; Rozuel and Kakabadse 2012; Vitellet al. 2016; Vu 2019; Vu and Tran, 2019).

Nicholas Burton

n.burton@northumbria.ac.uk

1 Northumbria University, City Campus East 1, Newcastle NE1 8ST, UK
This disregard is somewhat puzzling given that morals and ethics are deeply embedded in many spiritual and religious traditions (e.g., Corner 2009; Sheep 2006). Perhaps one possible explanation is that much of the spirituality at work literature has often remained uncritical and regards spirituality as a source of wholeness (Neal 1997; Sheep 2006) and an enabler of an integrated self-identity that underscores the idea of bringing a whole self to work. These kinds of conceptualizations often fail to adequately recognize that adherence to the teaching of many spiritual traditions often creates a high magnitude of moral dissonance for individuals in the workplace that can result in often painful and uncomfortable experiences (Rozuel 2011; Vu 2019). How spiritual practitioners negotiate moral dissonance is a significant gap in the business ethics literature, and this motivated us to unpack how individuals interpret their tradition-specific moral identity and negotiate moral dissonance at work. We draw upon moral identity and moral dissonance theory (e.g., Holland et al. 2002; Lowell 2012) and examine UK Quakers ${ }^{1}$ in work organizations. By doing

\footnotetext{
$\overline{1}$ This study examines UK Quakers. While Quakers' share similar testimonies throughout the world, Quaker theology has varied inter-
} 
so, we locate Quakerism within MacIntyre's conception of a tradition (MacIntyre 1988), and argue that the Quaker testimonies to truth, integrity, peace, simplicity and equality represent both a "storied and shared tradition" (Burton et al. 2018 , p. 360) and have some resemblance to a set of virtues (Scully 2009) that connect an individuals' moral identity to Quaker moral identity in an uncommonly direct way. While Quakerism emphasizes a constancy and continuity between the spiritual and social life, Quakers, like other religious and/or spiritual practitioners, are nevertheless not immune to experiencing moral dissonance.

We interviewed 34 Quaker manager-practitioners in the UK. To signpost our contribution, we uncover that while a Quaker moral identity is widely understood as a fusion of self, God and community, the work organization context presents significant challenges to sustaining an adherence to Quaker moral identity. We contribute to the moral identity literature in three important ways: first, we extend existing literature that has reported how spiritual practitioners pursue an undivided self through seeking a type of work that enables an expression of moral identity. In our study, spiritual practitioners more often preserved Quaker moral identity by outright disengaging from the work context, and we found many examples of exiting the organization and resignation in order to pursue alternative career choices. Second, we advance an understanding of moral identity in two distinctive ways: (1) we show how Quakers pursued either agentic negotiation strategies associated with identity compartmentalization, drawing upon the metaphor of a 'spiritual journey' as a form of self-justification for a divided moral identity and work identity; and (2) rather than dividing the self, we highlight how many Quakers compartmentalized and engaged only in work tasks that were perceived as moral and meaningful, while morally disengaging from others, suggesting a subjectively moral, rather than individuated, perspective to finding meaning in work.

Our paper is structured as follows: first, we locate our study in the moral identity and moral dissonance literature. Second, we briefly describe UK Quaker theology and tradition. Third, we elaborate our research method, and present our findings with example quotations from our participants. Fourth, we present a discussion of our findings and introduce our model. Lastly, we conclude with practical implications, and pathways and directions for future research.

\section{Footnote 1 (continued)}

pretations. In this study, we assume a "Liberal Quaker" theology (Dandelion 2004)

\section{Moral Identity and Moral Dissonance}

Moral identity is constructed in social contexts (Nelson 2011) through connection to and inclusion in specific communities (Bauman 1993). It refers to the extent to which individuals value a moral self-image and relate it to self-concept; it is a "kind of self-regulatory mechanism that motivates moral action" (Aquino and Reed 2002, p. 1423), and which influences ethical judgments (Weaver 2006; Trevino et al. 2006). When individuals have high levels of moral identity, they tend to value internalized moral standards and behave ethically and pro-socially (Detert et al. 2008; Reynolds and Ceranic 2007), drawing upon high levels of moral self-regulation (Aquino and Reed 2002; Zheng et al. 2019). On the other hand, individuals with low levels of moral identity may use self-serving justifications for individualistic or unethical behavior (Gino and Ariely 2012). For instance, Sanders et al. (2018) found that lower levels of moral identity affects managers' motivation to act selflessly, while managers with higher levels of moral identity are more likely to engage in ethical behavior.

Studies show that high levels of moral identity encourage individuals to see and judge the world through a moral lens, influencing attitudes, emotions and reactions (Aquino et al. 2011; Greenbaum et al. 2013; Jennings et al. 2015; Saunders et al. 2018; Zheng et al. 2019). As individuals engage in moral reasoning, self-regulatory mechanisms such as guilt and self-censure are activated to constrain individuals from engaging in unethical behavior. Individuals choose to maintain their values and beliefs that they consider good and moral (Bandura 1986; Batson et al. 2003; Cooper 2001; Haidt 2001; Haidt and Kesebir 2010; Tsang 2002) to preserve their appearance of morality. However, a conscious negotiation may be necessary when moral identity is exposed or open to question.

Moral dissonance arises when individuals with strong moral identity bow to contextual pressures to act unethically (Aquino and Backer 2005; Stets and Carter 2011), which threatens their self-esteem and induces psychological discomfort (Baumeister 1988; Mesdachinia et al. 2019). According to Festinger's (1957) cognitive dissonance thesis, inconsistencies in attitudes, beliefs, and behaviors lead to a state of cognitive dissonance, explaining how individuals negotiate and react to their own moral violations (Aqunino and Backer 2005; Moser 1988). In order to reduce it, individuals tend to moderate their actions or articulate selfjustifications for their unethical action (Lowell, 2012). In other words, cognitive dissonance can sometimes trigger self-justification, leading to a reappraisal of motives and self-concept in seeking to rationalize dissonant behavior. Similarly, moral dissonance tends to arise when individuals 
activate self-justification in response to something against their inherent sense of morality (Hauser 2007).

Contextual cues, such as the work organization, can also affect the way in which individuals think about morality (Leavitt et al. 2016), and which can cause high levels of moral dissonance. To moderate such dissonance, individuals tend to adopt strategies such as impression management as a form of self-justification (Cooper 2007; Holland et al. 2002; Lowell 2012), or self-affirmation as a form of moral rationalization that allow individuals to convince themselves that their unethical choice is consistent with moral standards (Tsang, 2002). Alternatively, as noted in a recent study by Mesdachinia et al. (2019), individuals with a strong moral identity that is in conflict with contextual cues can choose to leave the situation to restore their self-esteem and moral identity (Aquino and Becker 2005; Stets and Carter 2011).

\section{Compartmentalization}

When individuals experience moral dissonance it can often lead to identity compartmentalization (Bandura 1986, 1991, 2001,2006 ) which challenges the cultivation of an integrated moral identity, since individuals tend to decouple their internalized moral standards from external actions (Moore 2015) in order to rationalize and justify unethical or immoral behavior without guilt or self-censure (Bandura 1986). In other words, compartmentalization divides the self, depriving individuals of their moral strength (Rozuel 2011) and adherence to virtue (MacIntyre 1999). This kind of compartmentalization causes, either consciously or unconsciously, individuals to censor moral values creating a moral void that disengages with moral agency and puts pressure on moral identity (Rozuel 2011; Rozuel and Kakabadse 2010). Such censorship of moral identity presents a threat to the pursuit of a whole self (Gosis and Kortezi 2008) as it can separate values and ethics that are deemed inappropriate and irrelevant to the work context (Rozuel and Kakabadse 2010). For example, individuals may be empathetic in particular roles and contexts, such as home and social life, and yet engage in non-empathetic behaviors in the work organization context (MacIntyre 1999) where different rules of the game apply (Carr 1968).

Compartmentalization is exacerbated by many work organization contexts. Contemporary organizations are socially complex, which sometimes tempt individuals to comply with organizational moral norms encouraging selfjustification. Self-regulation of morality is not determined by internal factors alone, but in the process of social interaction with and through others (Newman et al. 2019). This process explains how corrupt behaviors are often normalized in organizations due to organizational structures and culture (Ashforth and Anand 2003; Moore2008; Vu 2019).
According to Bandura (1986), unethical behaviors are examples of failed self-regulatory processes where individuals have internalized organizational values to regulate and guide behavior. As a result, the work organization context tempts individuals to compartmentalize self-identity to function adaptively within it (Showers and Zeigler-Hill 2007).

Spirituality has been suggested as incorporating virtue (Cavanagh and Bandsuch 2002; Gotsis and Kortezi 2008) and as one means to resist identity compartmentalization, as spiritual practice deeply embeds moral and ethical conceptualizations of self (Corner 2009; Sheep 2006; Zhao and Biesta 2011) and helps to construct whole and authentic selves (Kinjersky and Skrypnek 2004; Neal 1999, 2000). However, spiritual individuals are not immune from identity compartmentalization and self-justification. For example, Brophy (2015) argues that in business contexts that advance economic interests, spiritual individuals compartmentalize their deeply held values to resolve workplace tensions. Similarly, in recent studies (Vu 2019; Vu and Tran 2019), Buddhist practitioners in work organization contexts justified their involvement in unethical bribery acts by using karmic reasoning as a utilitarian approach that foregrounded ends over means. The over-riding rationale that Buddhist practitioners articulated for using karmic reasoning to justify compartmentalization is that they have to be skillful and contextually sensitive to deal with unethical practices beyond their individual control.

\section{The Quaker Tradition}

Quakers have a history of over 350 years in the UK and a long-standing record of producing responsible businesses (Burton and Turnbull 2019; Walvin 1997). Its theology is diverse, varied and 'liquid' (Collins and Dandelion 2014), although central to Quakerism is the idea of the Light Within implanted by God in every person and a readiness to answer that of God in another (Dandelion 2004). Quakers tend not to worship a defined deity, widely reject the sacred/secular binary, and have no priesthood or other formalized hierarchy (Muers and Burton 2019), acknowledging the priesthood of all believers (Cranmer 2003).

Quakerism has Christian roots; however, its theology gives primacy to the interaction between individual and community experience (Muers and Burton 2019), guided and shaped by the Quaker testimonies to peace, truth, integrity, simplicity, and equality. The testimonies are "storied and shared traditions" (Burton et al. 2018, p. 360) that promote ethical ideals to indicate the good life and show how to build a better world. In Quaker Studies, Scully (2009) reported that virtue ethics is the preferred ethical framework for UK Quakers, and that Quakers would reject a deontological or utilitarian approach to ethics due to a rejection of 
epistemic closure (Dandelion 2004) and the primacy that Quakers grant to personal experience and experiential ways of knowing over creed or scripture (Muers 2015). Further, the value Quakers' place on social justice is unlikely to sit comfortably with utilitarian ethics. For Quakers, moral identity arises out of this storied and shared tradition of behavioral ethics (Wagner-Tsukamoto 2008). While the continuity of spiritual and social life is central to "Quaker morality," the Quaker testimonies are normative and yet allow space for an individual interpretation of the good life. In other words, moral dissonance has the potential to occur in the space between the context-embedded and normative 'rules of the game' and the 'moves of the games' made by individuals (see Hodgson 2006, p 9).

As Robson (2015) noted, traditions of virtue ethics become traditions by developing over time a set of virtues that become synonymous with that particular tradition. Religious and spiritual traditions have been the focus of some work in business ethics, for instance Islam (Rice 1999), Confucianism (Koehn 2019), Buddhism (Vu 2019), and Catholicism (Bernacchio 2019). According to Moore and Beadle (2006), virtues and the traditions in which they are located are best understood in context. The Quaker tradition is characterized by its theology and the expression of that theology in a social (non-Quaker) context through the Quaker testimonies. The testimonies represent the collective experience of Quakers revealed throughout history and are published and revised every generation or so by Quakers in Britain to provide inspiration and challenge to individual Quakers in their daily lives as part of a continuing process. It is from this perspective that we now turn to ground our investigation in the Quaker tradition.

\section{Methodology}

We collected interview data from individuals who described themselves as having a managerial role in an organization in the UK. We selected thirty-four participants from across twenty-three for-profit organizations in a number of different industries and sectors. The participants were either formal members or regular attenders of a UK Quaker meeting associated with the Religious Society of Friends (Quakers), and all participants were recruited at a UK Quakers \& Business conference held in London in 2017. The list of participants is shown in Table 1.

Each interview was conducted in a private meeting room for about one hour at the participants' workplace. We began the semi-structured interviews by describing to participants that we were interested in "self-identity" and "tensions in self-identity at work" to locate the discussion within our research interests. However, we allowed any connection to spirituality, morality or ethics to emerge during the interview process. The semi-structured interviews lasted around one hour and were conducted and transcribed by the lead author during 2018.

Template analysis was used to analyze the textual data. Our coding followed the approach developed by King (1998, 2004) which has gained traction in multiple disciplines such as psychology, sociology, healthcare, and management and organization studies (e.g., Burton and Galvin 2018; Waring and Wainwright 2008). Template analysis is a distinct and flexible type of thematic analysis that emphasizes hierarchal coding but balances structure with the flexibility to adapt it to the needs of a particular research study (King 2004). Preferring to allow themes to emerge from the data, we avoided pre-defining a priori codes. We created a template that enabled us to examine similarities and differences in themes. The templates were often modified during the data analysis phase. For example, we deleted various codes, merged lower level codes together, and changed the position of some codes in the template as the data analysis process continued. Where new themes emerged or other changes to the templates were made, previously analyzed interview transcripts were re-examined, and this iterative process continued ad-finetum. Finally, we were able to identify integrative themes that permeated most of the data, and these integrative themes are used to structure our findings to follow. The final template and examples of coding text to themes is shown in Table 2.

\section{Findings}

\section{Interpretation of Quaker Moral Identity and Quaker/ Work Identity Alignment}

The Quaker manager-practitioners in our study highlighted that moral identity is often constructed in relational and social contexts. For example, participants commented that:

[...] my moral self-hood is constructed in relation to others; I am a relational being. I am only distinguishable from others by reference to my ego, and my attempts at its suppression. (Q2, UK2)

God and I are inseparable. My morals are his morals. I try to live this out in my daily life as best I can. But I am not God, I am human, flawed, vulnerable, weak (Q18, UK11)

My 'self' is a member of God's precious community - an emanation of the divine power of creation. With the spiritual grounding of Quakerism, I feel my own thoughts, attitudes, and behaviors are more wholesome, and somehow better. My interpersonal 
Table 1 Respondents' characteristics

\begin{tabular}{|c|c|c|c|c|}
\hline Person reference & Gender & Position & $\begin{array}{l}\text { Company } \\
\text { reference }\end{array}$ & Sector \\
\hline Q1 & M & Production Manager & UK1 & Chemicals \\
\hline Q2 & M & General Manager & UK2 & Hospitality \\
\hline Q3 & $\mathrm{F}$ & Store Manager & UK3 & Retail \\
\hline Q4 & $\mathrm{F}$ & Assistant Store Manager & UK3 & Retail \\
\hline Q5 & $\mathrm{F}$ & Marketing Manager & UK4 & Publishing \\
\hline Q6 & M & Marketing Manager & UK4 & Charity \\
\hline Q7 & $\mathrm{F}$ & Theater Manager & UK5 & Arts \\
\hline Q8 & $\mathrm{F}$ & Marketing Manager & UK5 & Arts \\
\hline Q9 & $\mathrm{F}$ & Consultant & UK6 & Management consultancy \\
\hline Q10 & M & Trustee & UK6 & Charity \\
\hline Q11 & $\mathrm{F}$ & IT Manager & UK6 & Management consultancy \\
\hline Q12 & $\mathrm{F}$ & Governance Manager & UK7 & Charity \\
\hline Q13 & M & Campaign manager & UK7 & Charity \\
\hline Q14 & M & Investment Manager & UK8 & Financial services \\
\hline Q15 & $\mathrm{F}$ & Director & UK9 & Property \\
\hline Q16 & $\mathrm{F}$ & Marketing Head & UK10 & Charity \\
\hline Q17 & $\mathrm{F}$ & Membership Manager & UK10 & Charity \\
\hline Q18 & M & Head & UK11 & Enterprise \\
\hline Q19 & M & Consultant & UK12 & Management consultancy \\
\hline Q20 & M & Lawyer & UK13 & Law \\
\hline Q21 & M & Lawyer & UK13 & Law \\
\hline Q22 & M & Grants officer & UK14 & Charity \\
\hline Q23 & $\mathrm{F}$ & Manager & UK15 & Hotel \\
\hline Q24 & M & Manager & UK16 & Hotel \\
\hline Q25 & M & Director & UK17 & Conferencing \\
\hline Q26 & $\mathrm{F}$ & Executive Assistant & UK18 & Conferencing \\
\hline Q27 & M & Manager & UK19 & Conferencing \\
\hline Q28 & $\mathrm{F}$ & Director & UK20 & Financial Services \\
\hline Q29 & M & Non-executive & UK21 & Financial services \\
\hline Q30 & M & Production Manager & UK22 & Manufacturing \\
\hline Q31 & $\mathrm{F}$ & Company Secretary & UK22 & Manufacturing \\
\hline Q32 & $\mathrm{F}$ & Executive Assistant & UK22 & Manufacturing \\
\hline Q33 & $\mathrm{F}$ & Manager & UK23 & Hospitality \\
\hline Q34 & $\mathrm{F}$ & Manager & UK23 & Hospitality \\
\hline
\end{tabular}

connection with others and God is an inward reflection of my identity (Q4, UK3)

Selfhood is the Christian soul, and not inseparable [...] (Q24, UK16).

In these examples, Quaker moral identity centers around narratives to do with self-identity as a fusion of self, God/ spirit, and community that firmly represents the Quaker theological commitment to recognizing and responding to God/spirit in another and the idea of the Light Within. In other words, individuals recognize that self-hood is nonseparable from God/spirit within, and non-separable from God/spirit in another.
In line with much of the SAW literature, participants also remarked upon the continual search for wholeness and unity in the workplace, and of the effort to avoid identity compartmentalization. Further, self-wholeness was recognized as a goal attained through personal growth and self-transformation. For instance,

Self-identity is a contradictory notion. It is, on the one hand, a wholeness that is connected to all things in the universe. Yet, it is unique, temporary yet immortal. It is physical, and yet it isn't my body. It can grow and transform. Its essence is as a gifter and receiver of love and respect (Q15, UK9) 


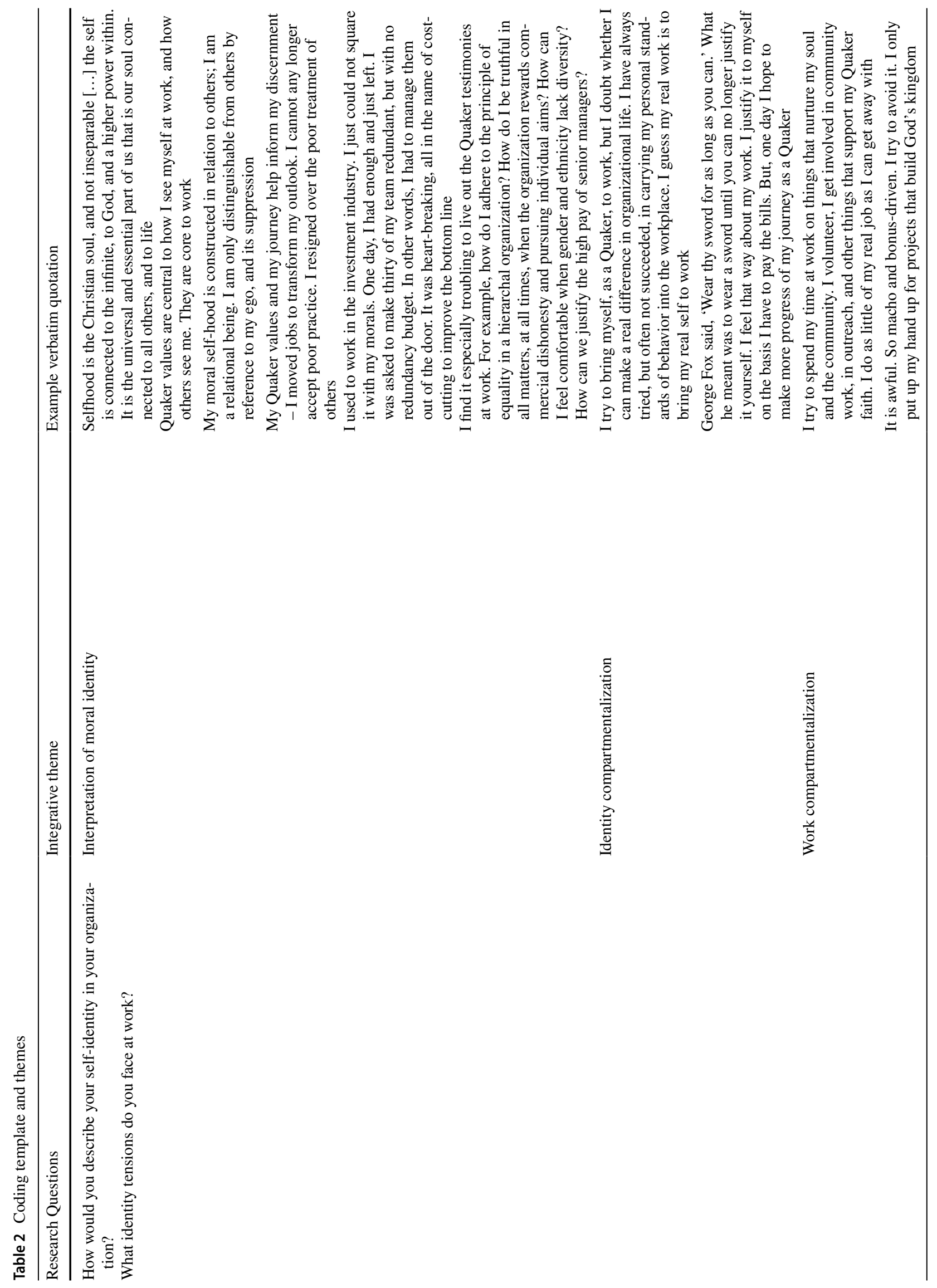


I try to find a wholeness, unity, not a fragmented self. A whole self enables me to bring love and respect to work, to modify my attitudes and action. Improvement is integral, I don't have all the answers, but any transformational change has to encompass spirit, mind and body so that I can express love, kindness, gratitude, and build God's kingdom on Earth. (Q2, UK2)

Many participants also elaborated how the practice of being a Quaker was located at the heart of the process through which self-identity is shaped. The practice of attending a 'Quaker meeting' was frequently referred to as an integral part of Quaker identity and as a spiritual mode through which a moral self could be 're-centered.' For example,

Silence and turning inwards is the process through which I deeply listen to God and that of God in others. These moments can be divine, and help me take my ego out of the equation (Q17, UK10)

Silence and stillness permit my moral self through prayer or meditation (Q16/UK10)

I refresh myself through daily prayer, meditation, reading scripture, and oftentimes I practice yoga. This helps me re-center my 'self,' and to rid myself of the moral dust of the world (Q32, UK22)

For many participants, the Quaker testimonies provided the moral guidance for individual and social action in the world. Adherence to the Quaker testimonies was judged by many participants as central to their workplace identity. Examples include:

Quaker testimonies allow me to focus on the bigger picture in work. What's really important beyond the minutiae. My real work at work is to live out those testimonies (Q17, UK10)

By fusing my professional and spiritual life, I now work entirely from a perspective of wholeness and service in life. I work with mindfulness and compassion. I emphasize integrity and values- led behavior, I question taken-for-granted practices, and have a real concern for equality and everyone having a voice. The Quaker testimonies are my guide (Q6, UK4)

Many participants referred to sustaining Quaker moral identity as important as a way to align moral identity and work identity. For example:

Quaker values are central to how I see myself at work, and how others see me. They are core to work (Q10, UK6)

Quaker values strongly influence my approach to my work life. I see myself as leading the organization towards positive change. The Quaker testimonies guide me in this endeavor. (Q13, UK7)

Quakerism guides my choice of employment. I currently work for a charity and have scope to live out my values at work by working in service of others with less power and privilege (Q22, UK14)

These examples show how Quaker testimonies and Quaker spiritual practice shape and inform moral identity through a morally reflexive practice of stillness, silence, prayer and meditation, and highlight the way in which the Quaker testimonies guide action in the service of the 'good life.'

\section{Quaker/Work Identity Dissonance}

The participants pursued various strategies to minimize moral dissonance. A number of participants narrated examples of a high magnitude of moral dissonance that resulted in exiting the organization and resignation as a way to preserve Quaker moral identity. For example, one participant commented that he had resigned over poor management practice,

My Quaker values and my journey help inform my discernment - I moved jobs to transform my outlook. I cannot any longer accept poor practice. I resigned over the poor treatment of others (Q33, UK23)

A further participant recounted his experience of work practices in the investment management sector that resulted in his resignation,

I used to work in the investment industry. I just could not square it with my morals. One day, I had enough and just left. I was asked to make thirty of my team redundant, but with no redundancy budget. In other words, I had to manage them out of the door. It was heart-breaking, all in the name of cost-cutting to improve the bottom line (Q2, UK2)

\section{Quaker/Work Identity Compartmentalization}

Despite the Quaker testimonies encouraging the 'right' moral disposition, Quaker manager-practitioners continually remarked about the tensions and dissonance associated with 'living out' the good life in the workplace. The following example indicates the tensions experienced when adhering to the Quaker testimonies to equality and truth.

I find it especially troubling to live out the Quaker testimonies at work. For example, how do I adhere to the principle of equality in a hierarchal organization? How do I be truthful in all matters, at all times, when the organization rewards dishonesty and individualism? How can I feel comfortable without diversity? 
How can I justify the high pay of senior managers? (Q20, UK13)

Sometimes, I just want to up and leave. I struggle with the very idea of business, as it is predicated upon deceit, making profits and not pursuing the common good. I just have to live with it the best I can (Q1, UK1).

In a number of examples, participants referred to the need to compartmentalize self-identity into a Quaker moral identity and a work identity in order to cope with moral dissonance in the workplace. For instance, one participant recounted the struggle of bringing a 'real self' to work,

I try to bring myself, as a Quaker, to work, but I doubt whether I can make a real difference in organizational life. I have always tried, but often not succeeded, in carrying my personal standards of behavior into the workplace. I guess my real work is to bring my real self to work (Q34, UK23)

A further respondent recognized the tensions between the economic imperatives of the workplace and adherence to Quaker teaching that resulted in reluctant acknowledgement that the work context is non-changeable and thus requires a change of 'self.' For instance,

I can transform my self, but I doubt whether I can transform the business world. I guess all I can really try to achieve at work is to overcome the lowest levels of ethical incompetence. The world of work is so challenging to my notion of self. Work aims to institutionalize, it is like a rope pulling you towards a materialistic self. For many, it is hard to resist. I try to resist it. But often I just have to hold my nose at work and get on with it (Q25, UK17)

One manager recalled how the materialistic culture of the work organization often usurped Quaker moral identity,

My worst moment has to be being awarded a big bonus, rushing out to buy a new car, and then a few weeks later recalling how some of my team had had no bonus. I should have shared it with them, or donated it to charity. But, my ego had won that one (Q3, UK3)

In justifying identity compartmentalization, participants frequently employed the metaphor of the spiritual journey as a self-justification for moral weakness. The participants described the spiritual journey as one of being...

Better tomorrow than today. It is a constant process, it is about being open to change through nature and community. It is about progress, not perfection. I work on my journey everyday (Q30, UK22)
George Fox said, 'Wear thy sword for as long as you can.' What he meant was to wear a sword until you can no longer justify it yourself. I feel that way about my work. I justify it to myself on the basis I have to pay the bills. But, one day I hope to make more progress of my journey as a Quaker (Q28, UK20)

The company is not always ethical and it sure doesn't match my own values. But, it's part of my journey. We are all on our own journey of discovery. Some make fast progress. Others make slower progress. I don't have all the answers. It's all a matter of where you are in your journey. (Q23, UK15)

As these examples highlight, the metaphor of the spiritual journey metaphor is often utilized as a self-justification for identity compartmentalization. Living in constant tension with Quaker testimonies is 'part of a journey' towards living the good life. The spiritual journey metaphor, however, was also utilized as a positive way to express the process of personal growth and self-transformation. The following example from a manager who had recently moved jobs illustrates,

Although I'm not perfect by any means, I feel my inner core is transforming as I progress on my journey. It enables me to move to living the best life I can, with grace and with sympathy towards others. My transformation has helped me respect each person, with their own personality, their own identity, it affects me in a deep way. (Q29, UK21)

\section{Work Compartmentalization}

While a number of participants remarked how they needed to compartmentalize self-identity in the workplace, many also narrated how they preserved their Quaker moral identity by reframing and compartmentalizing work tasks to more closely align with Quaker moral identity. In other words, participants expressed how they tried to compartmentalize 'work' into moral and meaningful work and non-moral work to preserve an undivided self. For instance,

Work is where I speak truth to power. Work is not a job. To be and effect the change we want to see in the world. My job has a job description, but really my real job is to build God's kingdom, right here, right now (Q3, UK3)

I try to spend my time at work on things that nurture my soul and the community. I volunteer, I get involved in community work, in outreach, and other things that support my Quaker faith. I do as little of my real job as I can get away with (Q19, UK12) 


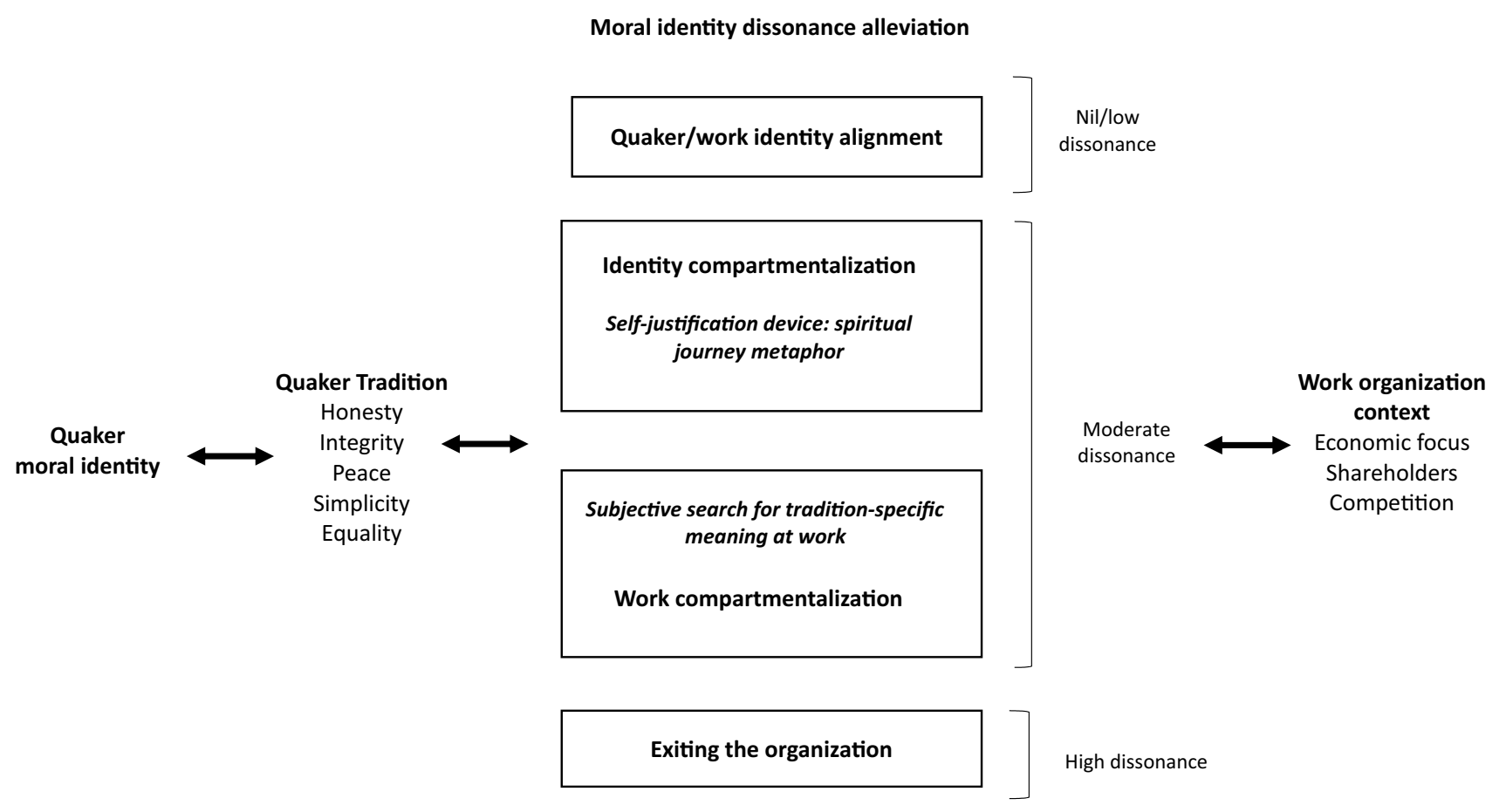

Fig. 1 Model of moral dissonance negotiation in the Quaker tradition

It is awful. So macho and bonus-driven. I try to avoid

it. I only put up my hand up for projects that build

God's kingdom (Q20, UK13)

Further, participants drew upon the idea of moral and meaningful work as a way to address moral dissonance. By compartmentalizing into moral and meaningful, and non-moral, participants described how...

I have to find some meaning at work. My day job is tiresome, money, money, money. I have to put this aside. For example, I try to get some meaning by volunteering for the good things my employer does. Last month, I participated in a sleep out to raise money for the homeless. That was satisfying (Q11, UK6).

Most work gives me no meaning. Unless I can carve out some time to do the work I want to. Luckily, my boss recognizes this, and I can spend a few days each month working at a charity that works with disadvantaged groups (Q32, UK22).

\section{Discussion}

Existing research has argued that the strength of an individuals' moral identity is closely related to the extent to which they regulate their behavior and behave morally or immorally (Lowell 2012). By grounding our study in the
Quaker tradition and Quaker practice, we have shown how individual Quakers interpret Quaker moral identity in line with both Quaker theology and the testimonies to peace, truth, integrity, simplicity, and equality. Our study highlights a rich and complex picture, and our findings contribute to the business ethics literature on moral identity and moral dissonance in a number of important ways.

First, our study highlights that Quakers seek an undivided self through an alignment between Quaker moral identity and work identity. We found that the attainment of alignment enabled our participants to bring their whole selves to work (e.g., Neal 1999; Tracey et al. 2006). Interestingly, we only found expressions of alignment in non-profit and third sector work contexts suggesting how living out Quaker testimonies in shareholder-owned organizations seems largely incompatible. Second, we find examples of Quakers' pursuing alignment by exiting the work organization and resigning in order to avoid the discomfort and pain of extreme moral dissonance. In this way, adherence to the teachings of Quakerism acted as a regulative ideal (e.g., Oakley and Cocking 2001) that governed how participants responded to unsettling moral experiences. Third, in cases of 'moderate' levels of moral dissonance, our study highlights how Quakers engaged in identity compartmentalization in which participants compartmentalized identity into Quaker identity and work identity, a process which was often uncomfortable, painful, and required self-justification through the use of a spiritual journey metaphor. Otherwise, many participants 
engaged in work compartmentalization as they sought to engage only in work tasks subjectively perceived as 'moral and meaningful,' while morally disengaging from 'nonmoral and meaningless' work tasks. These processes of moral identity negotiation are presented in Fig. 1.

\section{Theoretical Contribution}

\section{The Undivided Self}

According to MacIntyre (1999), different social spheres create a pressure to compartmentalize self-identity between various roles, and we become unable to adjudicate between competing demands. In the Quaker tradition, the theology of unity with God and an emphasis on continuity between the spiritual and social life suggests that Quakers are wellplaced to resist the compartmentalizing pressure of work. The participants in our study highlighted how Quakerism was central to their conception of moral identity and work identity. The way in which Quakers described self-identity emphasized the centrality of self and its connection to God. For some, Quaker moral identity and work identity were not compartmentalized, work was seen as a 'calling' in the service of God (e.g., Neubert and Halbesleben 2015; Word 2012) and an intense experience bringing fulfillment (Dobrow and Tosti-Kharas 2011; Wrzesniewski et al. 1997), re-affirming much of the existing SAW literature that has reported an undivided self is important to spiritual practitioners (e.g., Corner 2009; Neal 1999; Sheep2006; Zhao and Biesta 2011). However, our study extends this stream of research. We found many examples (exclusively shareholderowned organizations) where participants experienced a high magnitude of moral dissonance and sought to avoid it by resigning and exiting from the work organization in order to preserve an undivided Quaker moral identity. In other words, preserving moral identity, at least in the Quaker tradition, can lead to behaviors and actions that may have severe, personal economic costs.

Our findings, however, reject much of the SAW and business ethics literature that has uncritically suggested that spirituality at work is a win-win (eg, Brophy 2015; Fry and Cohen 2009; Neal 1999). Rather, our study highlights how many Quakers actively negotiated moral identity through compartmentalization in two important ways: identity compartmentalization or work compartmentalization.

\section{Identity Compartmentalization}

Compartmentalization consists of fragmenting one's life into exclusive categories (e.g., Rozuel 2011; Wilcox 2012). The Quaker moral identity relies upon a moral code in contrast to work identities that are often individualistic and can tempt us to act in a self-serving way which "inhibit[s] the exercise of the powers of moral agency" (MacIntyre 1999 , p. 327). Individuals do not often compartmentalize self-identity unless they are able to find reasons to justify it in a way that serves self-rationalization (eg, Johnson and Buckley 2015; Lowell 2012). For example, in a study of Buddhist leaders and identity ( Vu 2019), even when the importance of community well-being is used to justify acts of bribery, personal struggles and guilt were found.

Our study highlights that many Quakers compartmentalized their Quaker and work identities utilizing a process of self-justification using a spiritual journey metaphor. In Quakerism, a spiritual journey metaphor implies a positive sense of self-transformation, a path forward, and progress (Kline2012; Molina-Markham 2012). When deployed in a positive sense, the metaphor has an affinity with the Quaker idea of 'experimental' knowing. According to Muers (2015, p. 15), claims to knowledge are based on personal experience that arise from right action, and they serve in turn as the basis for further 'experiments,' and thus the individual and collective experience of Quakers form part of a continuing process. This idea accords with the notion that the Quaker spiritual journey is continuous and unending.

However, in our study, many Quakers' also used the spiritual journey metaphor to justify identity compartmentalization between Quaker and work identities to convince themselves that their non-moral choices simply formed part of an ongoing unevenness or deferment in spiritual progression or attainment. Thus, our study highlights that self-justification can be a painful and uncomfortable experience that can challenge adherence to Quaker testimonies. One quotation that illuminates the tensions is a reference to the Journal of George Fox, the founding figure of Quakerism: "George Fox said, 'Wear thy sword for as long as you can.' What he meant was to wear a sword until you can no longer justify it yourself. I feel that way about my work. I justify it to myself on the basis I have to pay the bills. But, one day I hope to make more progress of my journey as a Quaker." In this quotation, Quaker theology and the spiritual journey metaphor is used to justify a divided self and that progress on the spiritual journey can be deferred in favor of more immediate economic concerns. As a consequence, instead of dividing self, many participants subjectively compartmentalized work tasks into moral and meaningful work and non-moral and meaningless work as an alternative strategy.

\section{Work Compartmentalization}

Many participants subjectively reframed and compartmentalized work tasks as moral and meaningful or as non-moral and meaningless, and disengaged from the latter. Our study 
therefore extends prior scholarship on meaningful work such as Lips-Wiersma and Morris (2009) who noted that individuals' attained meaning in work by selecting work tasks that encouraged self-development, relational unity and service, and the literature on job-crafting (e.g., Berg et al. 2010; Pajo and Lee 2011; Wrzesniewski and Dutton 2001; Yeoman 2014). In our study, we advance this scholarship by unpacking how Quakers' compartmentalized the work tasks that they engaged in, in line with their 'general calling' predicated upon normative commitments of living a 'good life,' building upon McPherson (2013) and Michaelson (2019), while morally disengaging from others. Compartmentalizing work indicates that Quakers' moral identity and the need to preserve an undivided self deeply influence how identity is shaped by the Quaker tradition. Our participants recounted numerous examples of engaging only in work tasks associated with prosocial ends, while disengaging from work tasks they subjectively associated with purely financial or economic ends. Thus, we advance existing literature by suggesting that spiritual practitioners, or at least Quakers, may seek to resist identity compartmentalization and turn to other non-conformist or deviant ways to preserve their moral identity. In contexts characterized by a high magnitude of moral dissonance, this may be through exiting the organization. In other 'moderate' cases, they may compartmentalize work tasks and engage only in those that preserve their moral identity. Thus, we also go beyond the traditionagnostic character of much existing research on moral identity, and show how the tradition-specific Quaker testimonies informed and shaped the work compartmentalization process. By going deeper into the theological and philosophical content of the Quaker tradition, we have been able to uncover precise linkages between Quaker moral identity and meaningful/moral work.

In our examples of Quaker/work identity alignment, participants' adherence to moral tradition was an important driver for an experience of meaningful work (e.g., Bailey et al. 2016; Lips-Wiersma and Morris 2009; Schnell et al. 2013), in contrast to the often individualistic expressions of meaningful work, such as autonomy (e.g., Bowie 1998; Bailey and Madden 2017; Berge et al. 2010; Hurst 2014; Schwartz 1982), or desired work and job design (e.g., Cardador and Pratt 2006; Hackman and Oldham 1975; Shamir 1991).

However, there are paradoxical experiences in how individuals negotiate the multidimensionality of meaningful work arising from fulfilling a wider social good versus self-fulfillment (Bailey et al. 2019). Paradoxical experiences of meaningful work were evident in our examples as Quakers had to compartmentalize their identity to fit in with organizational culture and others' expectations to gain acceptance and recognition within the work organization (Obodaru2012; Schalk 2011). Such subjective experiences can be problematic leading to painful and uncomfortable feelings. Further, in the absence of a moral consensus (e.g., see Michaelson et al. 2014), our study illustrates that meaningful work can be defined, not in terms of individualistic criteria, but in terms of the morality of a specific tradition. Many participants created their own tradition-specific version of what they perceived as moral and meaningful and set the conditions under which they engaged (Michaelson 2019). This shows how they defended their moral agency, and the right to choose work that is meaningful to them (Arneson 1987; Bowie 1998; Care 1984; Schwartz 1982).

While much existing literature on moral identity construction has featured either agentic or contextual explanations (e.g., Jennings et al. 2015; Saunders et al. 2018; Zheng et al. 2019), our study has explored the interplay between agency and context to reveal how Quakers' balance moral and work identity by either working in organizations that enable moral alignment, or by exiting organizations where a high magnitude of moral dissonance is present. In other cases, Quakers' strategized to compartmentalize their Quaker and work identity, or actively engaged in work compartmentalization to minimize moral dissonance and preserve an undivided self. In this way, our study responds directly to the call for scholarship that develops multi-layered explanations for ethical or moral behavior (e.g., Hiekkataipale and Lämsä 2019).

\section{Practical Implications and Future Pathways}

Our study has a number of practical implications for business ethics scholarship. For example, some organizational leaders may well express concerns about the role of spirituality or religion in organizations. While spiritual expression is often perceived as a win-win, our study highlights a possible dark side. Non-conformist behaviors such as work compartmentalization may have profound implications for many work organizations, and leaders should consider its impact upon organizational culture, as well as on team and group dynamics and on co-workers. By locating 'meaning' only in work tasks that align with the Quaker tradition, our study suggests that spiritual practitioners could be a destabilizing force in the workplace. Given that spirituality is linked to organizational citizenship behaviors (e.g., Chen and Yang 2012) and prosocial motivations (Guillén et al. 2015; Saroglou 2006), spirituality can be a force for good in work organizations; however, an improved understanding of spiritual traditions by leaders, not spirituality per se, is needed to leverage this possibility. Our study suggests that the ways in which spiritual practitioners minimize moral dissonance is not straightforward. As such, a onesize-fits-all response by organizations is probably unwarranted. Rather, our study supports the idea of personal conversations around the 'meaning of meaningful work' 
in order to avoid individuals exiting the organization or engaging in non-conformist behavior.

A number of future research pathways are evident. First, work compartmentalization suggests a special kind of moral disengagement. Quakers disengaged from work organization tasks to give primacy to Quaker moral identity. Thus, the idea that the economic rationale of many organizations can corrupt an individuals' morals and ethics is not straightforward or linear. Identity compartmentalization suggests that an individual often disengages from her own moral tradition and in an organizational context acts in a self-serving manner (e.g., Barsky 2011; Fida et al. 2015; Moore 2008), and yet work compartmentalization suggests quite the opposite. Thus, further research that explores the types of strategies that spiritual practitioners use to preserve their moral identity would be welcome. Second, our study has shown how metaphors were used by Quakers as a self-justification for identity compartmentalization. Further research that examines how metaphors, narratives, and other cultural logics are used to justify self-serving behavior is a further possibility. Third, our study highlights how the Quaker tradition shapes an experience of meaningful work by reference to the tradition, in contrast to much of the individualistic expressions of meaning in the literature. Further research could address an exploration of moral issues that concern the management of normative considerations, as well their impact upon others and business ethics more generally. Research should consider whether there are definable characteristics to meaningful work to which we have moral rights and whether there are moral duties to ourselves and/ or others to fulfill those rights. Fourth, further research could explicitly link the theological or moral foundations of other Quaker traditions (such as the Evangelical Quaker movement in the US), or other religious or spiritual traditions, to moral identity and moral dissonance negotiation.

Funding This study received no funding.

\section{Compliance with Ethical Standards}

Conflicts of interest The authors declare no conflicts of interest.

Ethical Approval All procedures performed in the study involving human participants were in accordance with the ethical standards of the institutional research committee and with the 1964 Helsinki Declaration and its later amendments or comparable ethical standards.

Open Access This article is licensed under a Creative Commons Attribution 4.0 International License, which permits use, sharing, adaptation, distribution and reproduction in any medium or format, as long as you give appropriate credit to the original author(s) and the source, provide a link to the Creative Commons licence, and indicate if changes were made. The images or other third party material in this article are included in the article's Creative Commons licence, unless indicated otherwise in a credit line to the material. If material is not included in the article's Creative Commons licence and your intended use is not permitted by statutory regulation or exceeds the permitted use, you will need to obtain permission directly from the copyright holder. To view a copy of this licence, visit http://creativecommons.org/licenses/by/4.0/.

\section{References}

Aquino, K., \& Becker, T. E. (2005). Lying in negotiations: How individual and situational factors influence the use of neutralization strategies. Journal of Organizational Behavior: The International Journal of Industrial, Occupational and Organizational Psychology and Behavior, 26(6), 661-679.

Aquino, K., McFerran, B., \& Laven, M. (2011). Moral identity and the experience of moral elevation in response to acts of uncommon goodness. Journal of Personality and Social Psychology, 100(4), 703-718.

Aquino, K., \& Reed, I. I. (2002). The self-importance of moral identity. Journal of Personality and Social Psychology, 83(6), 1423.

Arneson, R. J. (1987). Meaningful work and market socialism. Eth ics, 97, 517-545.

Ashforth, B. E., \& Anand, V. (2003). The normalization of corruption in organizations. Research in Organizational Behavior, 25, 1-52.

Bailey, C., Lips-Wiersma, M., Madden, A., Yeoman, R., Thompson, M., \& Chalofsky, N. (2019). The five paradoxes of meaningful work: Introduction to the special issue 'meaningful work: Prospects for the 21st century'. Journal of Management Studies, 56(3), 481-499.

Bailey, C., \& Madden, A. (2017). Time reclaimed: Temporality and meaningful work. Work, Employment and Society, 31, 3-18.

Bailey, C., Madden, A., Alfes, K., Shantz, A., \& Soane, E. (2016). The mis-managed soul: Existential labor and the erosion of meaningful work. Human Resource Management Review, 27, 416-430.

Bandura, A. (1986). Social foundations of thought and action: A social cognitive theory. Englewood Cliffs: Prentice-Hall.

Bandura, A. (1991). Social cognitive theory of moral thought and action. In W. M. Kutrines \& J. L. Gewirtz (Eds.), Handbook of moral behavior and development (Vol. 1, pp. 45-104). New Jersey: Lawrence Erlbaum Associates.

Bandura, A. (2001). Social cognitive theory: An agentic perspective. Annual Review of Psychology, 52, 1-26.

Bandura, A. (2006). Toward a psychology of human agency. Perspectives on Psychological Science, 1(2), 164-180.

Barsky, A. (2011). Investigating the effects of moral disengagement and participation on unethical work behavior. Journal of Business Ethics, 104(1), 59-75.

Batson, C. D., Lishner, D. A., Carpenter, A., Dulin, L., HarjusolaWebb, S., Stocks, E. L., et al. (2003). “.. As you would have them do unto you": Does imagining yourself in the other's place stimulate moral action? Personality and Social Psychology Bulletin, 29(9), 1190-1201.

Bauman, Z. (1993). Racism, anti-racism, and moral progress. Arena Journal, $1,9$.

Baumeister, R. (1988). The self. In S. Gilbert (Ed.), The Handbook of Social Psychology (pp. 680-740). Boston, MA: McGraw-Hill.

Berg, J. M., Grant, A. M., \& Johnson, V. (2010). When callings are calling: Crafting work and leisure in pursuit of unanswered occupational callings. Organization Science, 21(5), 973-994.

Bernacchio, C. (2019). Pope Francis on conscience, gradualness, and discernment: Adapting Amoris Laetitia for business ethics. Business Ethics Quarterly, 29(4), 437-460. 
Bowie, N. E. (1998). A Kantian theory of meaningful work. Journal of Business Ethics, 17, 1083-1092.

Brophy, M. (2015). Spirituality incorporated: Including convergent spiritual values in business. Journal of Business Ethics, 132(4), 779-794.

Burton, N., \& Galvin, P. (2018). Using template and matrix analysis: A case study of management and organisation history research. Qualitative Research in Organizations and Management: An International Journal, 14(4), 393-409.

Burton, N., Koning, J., \& Muers, R. (2018). Organizational ethnography and religious organizations: The case of Quaker decision-making. Journal of Management, Spirituality \& Religion, 15(4), 349-367.

Burton, N., \& Turnbull, R. (2019). Quakers, business and corporate responsibility. Switzerland: Springer Press.

Cardador, M., \& Pratt, M. (2006). Identification management and its bases: bridging management and marketing perspectives through a focus on affiliation dimensions. Journal of the Academy of Marketing Science, 34(2), 174-184.

Care, N. (1984). Career choice. Ethics, 94, 283-302.

Carr, A. (1968). Is business bluffing ethical. Harvard Business Review, $143,155$.

Cavanagh, G. F., \& Bandsuch, M. R. (2002). Virtue as a benchmark for spirituality in business. Journal of Business Ethics, 38(1-2), 109-117.

Chen, C. Y., \& Yang, C. F. (2012). The impact of spiritual leadership on organizational citizenship behavior: A multi-sample analysis. Journal of Business Ethics, 105(1), 107-114.

Collins, P., \& Dandelion, P. (2014). Transition as Normative: British Quakerism as liquid religion. Journal of Contemporary Religion, 29(2), 287-301.

Cooper, J. (2001). Motivating cognitive change: The self-standards model of dissonance. In J. P. Forgas, K. D. Williams, \& S. C. Wheeler (Eds.), The social mind: Cognitive and motivational aspects of interpersonal behavior (pp. p72-91). New York: Cambridge University Press.

Cooper, J. (2007). Cognitive dissonance: 50 years of a classic theory. London: Sage.

Corner, P. D. (2009). Workplace spirituality and business ethics: Insights from an eastern spiritual tradition. Journal of Business Ethics, 85(3), 377-389.

Cranmer, F. (2003). Regulation within the religious society of friends. Ecclesiastical Law Journal, 7(33), 176-194.

Dandelion, P. (2004). Research note: Implicit conservatism in liberal religion: British Quakers as an 'uncertain sect'. Journal of Contemporary Religion, 19(2), 219-229.

Detert, J. R., Treviño, L. K., \& Sweitzer, V. L. (2008). Moral disengagement in ethical decision making: A study of antecedents and outcomes. Journal of Applied Psychology, 93(2), 374.

Dobrow, S., \& Tosti-Kharas, J. (2011). Calling: the development of a scale-measure. Personnel Psychology, 64(4), 1001-1049.

Festinger, L. (1957). A theory of cognitive dissonance. Stanford, CA: Stanford University.

Fida, R., Paciello, M., Tramontano, C., Fontaine, R. G., Barbaranelli, C., \& Farnese, M. L. (2015). An integrative approach to understanding counterproductive work behavior: The roles of stressors, negative emotions, and moral disengagement. Journal of Business Ethics, 130(1), 131-144.

Fry, L. W., \& Cohen, M. P. (2009). Spiritual leadership as a paradigm for organizational transformation and recovery from extended work hours cultures. Journal of Business Ethics, 84(2), 265-278.

Gino, F., \& Ariely, D. (2012). The dark side of creativity: Original thinkers can be more dishonest. Journal of Personality and Social Psychology, 102(3), 445.
Gotsis, G., \& Kortezi, Z. (2008). Philosophical foundations of workplace spirituality: A critical approach. Journal of Business Ethics, 78(4), 575-600.

Greenbaum, R. L., Mawritz, M. B., Mayer, D. M., \& Priesemuth, M. (2013). To act out, to withdraw, or to constructively resist? Employee reactions to supervisor abuse of customers and the moderating role of employee moral identity. Human Relations, 66(7), 925-950.

Guillén, M., Ferrero, I., \& Hoffman, W. M. (2015). The neglected ethical and spiritual motivations in the workplace. Journal of business ethics, 128(4), 803-816.

Hackman, R., \& Oldham, G. R. (1975). Development of the job diagnostic survey. Journal of Applied Psychology, 60, 159-170.

Haidt, J. (2001). The emotional dog and its rational tail: A social intuitionist approach to moral judgment. Psychological Rreview, 108(4), 814.

Haidt, J., \& Kesebir, S. (2010). Morality. In S. T. Fiske, D. T. Gilbert, \& G. Lindzey (Eds.), Handbook of social psychology. Hoboken, NJ: Wiley.

Hauser, M. D. (2007). Moral minds: How nature designed our universal sense of right and wrong. London: Little Brown.

Hiekkataipale, M. M., \& Lämsä, A. M. (2019). (A)moral agents in organisations? The significance of ethical organisation culture for middle managers' exercise of moral agency in ethical problems. Journal of Business Ethics, 155(1), 147-161.

Hodgson, G. (2006). What are instututions? Journal of Economic Issues, 40(1), 1-25.

Holland, R. W., et al. (2002). Dissonance on the road: Self-esteem as a moderator of internal and external self-justification strategies. Personality and Social Psychology Bulletin, 28, 1713-1724.

Hurst, A. (2014). The purpose economy: How your desire for impact, personal growth and community is changing the world. Boise: Elevate.

Jennings, P. L., Mitchell, M. S., \& Hannah, S. T. (2015). The moral self: A review and integration of the literature. Journal of Organizational Behavior, 36(S1), S104-S168.

Johnson, J. F., \& Buckley, M. R. (2015). Multi-level organizational moral disengagement: Directions for future investigation. Journal of Business Ethics, 130(2), 291-300.

King, N. (1998). Template analysis. In G. Symon \& C. Cassell (Eds.), Qualitative methods and analysis in organisational research (pp. 118-134). London: Sage.

King, N. (2004). Using templates in the thematic analysis of texts. In G. Symon \& C. Cassell (Eds.), Qualitative methods and analysis in organisational research (pp. 256-270). London: Sage.

Kinjersky, V., \& Skrypnek, B. (2004). Defining spirit at work: finding common ground. Journal of Organizational Change Management, 17(1), 26-42.

Kish-Gephart, J., Detert, J., Treviño, L. K., Baker, V., \& Martin, S. (2014). Situational moral disengagement: Can the effects of self-interest be mitigated? Journal of Business Ethics, 125(2), 267-285.

Kline, D. A. (2012). The Quaker journey and the framing of corporate and personal belief. Ethos, 40(3), 277-296.

Leavitt, K., Zhu, L., \& Aquino, K. (2016). Good without knowing it: Subtle contextual cues can activate moral identity and reshape moral intuition. Journal of Business Ethics, 137(4), 785-800.

Lips-Wiersma, M., \& Morris, L. (2009). Discriminating between 'meaningful work' and the 'management of meaning'. Journal of Business Ethics, 88(3), 491-511.

Lowell, J. (2012). Managers and moral dissonance: Self justification as a big threat to ethical management? Journal of Business Ethics, 105(1), 17-25.

MacIntyre, A. (1988). Whose justice? Which rationality?. London: Duckworth. 
MacIntyre, A. (1999). Social structures and their threats to moral agency. Philosophy, 74(3), 311-329.

McFerran, B., Aquino, K., \& Duffy, M. (2010). How personality and moral identity relate to individuals' ethical ideology. Business Ethics Quarterly, 20(1), 35-56.

McGhee, P., \& Grant, P. (2017). The transcendent influence of spirituality on ethical action in organizations. Journal of Management, Spirituality \& Religion, 14(2), 160-178.

McPherson, D. (2013). Vocational virtue ethics: Prospects for a virtue ethic approach to business. Journal of Business Ethics, 116(2), 283-296.

Mesdaghinia, S., Rawat, A., \& Nadavulakere, S. (2019). Why moral followers quit: Examining the role of leader bottom-line mentality and unethical pro-leader behavior. Journal of Business Ethics, 159(2), 491-505.

Michaelson, C., Pratt, M. G., Grant, A. M., \& Dunn, C. P. (2014). Meaningful work: Connecting business ethics and organization studies. Journal of Business Ethics, 121(1), 77-90.

Michaelson, M. (2019). A normative meaning of meaningful work. Journal of Business Ethics. https://doi.org/10.1007/s1055 1-019-04389-0.

Molina-Markham, E. (2012). Lives that preach: The cultural dimensions of telling one's "spiritual journey" among Quakers. Narrative Inquiry, 22(1), 3-23.

Moore, C. (2008). Moral disengagement in processes of organizational corruption. Journal of Business Ethics, 80(1), 129-139.

Moore, C. (2015). Moral disengagement. Current Opinion in Psychology, 6, 199-204.

Moore, G., \& Beadle, R. (2006). In search of organizational virtue in business: Agents, goods, practices, institutions and environments. Organization studies, 27(3), 369-389.

Moser, M. R. (1988). Ethical conflict at work: A critique of the literature and recommendations for future research. Journal of Business Ethics, 7(5), 381-387.

Muers, R. (2015). Testimony: Quakerism and theological ethics. London: SCM Press.

Muers, R., \& Burton, N. (2019). Can we take the religion out of religious decision-making? The Case of Quaker Business Method. Philosophy of Management, 18(3), 363-374.

Neal, C. (1999). A conscious change in the workplace. The Journal of Quality and Participation, 22(2), 27-30.

Neal, J. A. (1997). Spirituality in management education: A guide to resources. Journal of Management Education, 21(1), 121-139.

Neal, J. (2000). Work as service to the divine. American Behavioral Scientist, 43(8), 1316-1333.

Nelson, N. H. (2011). Damaged identities, narrative repair. New York: Cornell University.

Neubert, M. J., \& Halbesleben, K. (2015). Called to commitment: An examination of relationships between spiritual calling, job satisfaction, and organizational commitment. Journal of Business Ethics, 132(4), 859-872.

Newman, A., Le, H., North-Samardzic, A., \& Cohen, M. (2019). Moral disengagement at work: A review and research agenda. Journal of Business Ethics. https://doi.org/10.1007/s1055 1-019-04173-0.

Noval, L. J., \& Hernandez, M. (2019). The unwitting accomplice: How organizations enable motivated reasoning and self-serving behavior. Journal of Business Ethics, 157(3), 699-713.

Oakley, J., \& Cocking, D. (2001). Virtue ethics and professional roles. Cambridge: Cambridge University Press.

Obodaru, O. (2012). The self not taken: How alternative selves develop and how they influence our professional lives. Academy of Management Review, 37, 34-57.

Pajo, K., \& Lee, L. (2011). Corporate-sponsored volunteering: A work design perspective. Journal of Business Ethics, 99(3), 467-482.
Reynolds, S. J., \& Ceranic, T. L. (2007). The effects of moral judgment and moral identity on moral behavior: An empirical examination of the moral individual. Journal of Aapplied Psychology, 92(6), 1610.

Rice, G. (1999). Islamic ethics and the implications for business. Journal of Business Ethics, 18(4), 345-358.

Robson, A. (2015). Constancy and integrity:(un) measurable virtues? Business Ethics: A European Review, 24, S115-S129.

Rozuel, C. (2011). The moral threat of compartmentalization: Self, roles and responsibility. Journal of Business Ethics, 102(4), 685-697.

Rozuel, C., \& Kakabadse, N. (2010). Ethics, spirituality and self: Managerial perspective and leadership implications. Business Ethics: A European Review, 19(4), 423-436.

Sanders, S., Wisse, B., Van Yperen, N. W., \& Rus, D. (2018). On ethically solvent leaders: The roles of pride and moral identity in predicting leader ethical behavior. Journal of Business Ethics, 150(3), 631-645.

Saroglou, V. (2006). Religion's role in prosocial behavior: Myth or reality. Religion, 31(2), 1-66.

Schalk, S. (2011). Self, other and other-self: Going beyond the self/ other binary in contemporary consciousness. Journal of Comparative Research in Anthropology and Sociology, 2, 197-210.

Schnell, T., Höge, T., \& Pollet, E. (2013). Predicting meaning in work: Theory, data, implications. The Journal of Positive Psychology, 8(6), 543-554.

Schwartz, A. (1982). Meaningful work. Ethics, 92(4), 634-646.

Scully, J. L. (2009). Virtuous friends: Morality and Quaker identity. Quaker Studies, 14(1), 108-122.

Shamir, B. (1991). Meaning, self, and motivation in organizations. Organization Studies, 12, 405-424.

Shao, R., Aquino, K., \& Freeman, D. (2008). Beyond moral reasoning: A review of moral identity research and its implications for business ethics. Business Ethics Quarterly, 18(4), 513-540.

Sheep, M. L. (2006). Nurturing the whole person: The ethics of workplace spirituality in a society of organizations. Journal of Business Ethics, 66(4), 357-375.

Showers, C. J., \& Zeigler-Hill, V. (2007). Compartmentalization and integration: The evaluative organization of contextualized selves. Journal of Personality, 75(6), 1181-1204.

Stets, J. E., \& Carter, M. J. (2011). The moral self: Applying identity theory. Social Psychology Quarterly, 74, 192-215.

Tracey, R., Young, J. S., \& Kelley, V. A. (2006). Relationships between adult workers' spiritual well-being and job satisfaction: A preliminary study. Counseling and Values, 50, $165-177$.

Treviño, L. K., Weaver, G. R., \& Reynolds, S. J. (2006). Behavioral ethics in organizations: A review. Journal of Management, 32(6), 951-990.

Tsang, J. A. (2002). Moral rationalization and the integration of situational factors and psychological processes in immoral behavior. Review of General Psychology, 6(1), 25-50.

Vitell, S. J., King, R. A., Howie, K., Toti, J. F., Albert, L., Hidalgo, E. R., et al. (2016). Spirituality, moral identity, and consumer ethics: A multi-cultural study. Journal of Business Ethics, 139(1), 147-160.

Vu, M. C. (2019). Tensions and struggles in tackling bribery at the firm level: Perspectives from Buddhist-enacted organizational leaders. Journal of Business Ethics. https://doi.org/10.1007/ s10551-019-04235-3.

Vu, M. C., \& Tran, T. (2019). Trust issues and engaged Buddhism: The triggers for skillful managerial approaches. Journal of Business Ethics. https://doi.org/10.1007/s10551-019-04273-x.

Wagner-Tsukamoto, S. (2008). Contrasting the behavioural business ethics approach and the institutional economic approach to 
business ethics: Insights from the study of Quaker employers. Journal of Business Ethics, 82(4), 835-850.

Walvin, J. (1997). The Quakers: Money and morals. London: John Murray.

Waring, T., \& Wainwright, D. (2008). Issues and challenges in the use of template analysis: Two comparative case studies from the field. Electronic Journal of Business Research Methods, 6(1), 85-94.

Weaver, G. R. (2006). Virtue in organizations: Moral identity as a foundation for moral agency. Organization studies, 27(3), $341-368$.

Wilcox, T. (2012). Human resource management in a compartmentalized world: Whither moral agency? Journal of Business Ethics, $111(1), 85-96$.

Word, J. (2012). Engaging work as a calling: Examining the link between spirituality and job involvement. Journal of management, spirituality \& religion, 9(2), 147-166.

Wrzesniewski, A., \& Dutton, J. E. (2001). Crafting a job: Revisioning employees as active crafters of their work. Academy of Management Review, 26(2), 179-201.
Wrzesniewski, A., McCauley, C., Rozin, P., \& Schwartz, B. (1997). Jobs, careers and callings: peoples relations to their work. Journal of Research in Personality, 31, 21-33.

Yeoman, R. (2014). Conceptualising meaningful work as a fundamental human need. Journal of Business Ethics, 125(2), 235-251.

Zhao, K., \& Biesta, G. J. (2011). Lifelong learning between "East" and "West": Confucianism and the reflexive project of the self. Interchange, 42(1), 1-20.

Zheng, X., Qin, X., Liu, X., \& Liao, H. (2019). Will creative employees always make trouble? Investigating the roles of moral identity and moral disengagement. Journal of Business Ethics, 157, 653-672.

Publisher's Note Springer Nature remains neutral with regard to jurisdictional claims in published maps and institutional affiliations. 